\title{
Climate Change and Eutrophication: A Short Review
}

\author{
Mohammad Nazari-Sharabian \\ Department of Civil and Environmental \\ Engineering and Construction, \\ University of Nevada, Las Vegas, Las \\ Vegas, USA \\ nazarish@unlv.nevada.edu
}

\author{
Sajjad Ahmad \\ Department of Civil and Environmental \\ Engineering and Construction, \\ University of Nevada Las Vegas, Las \\ Vegas, USA \\ sajjad.ahmad@unlv.edu
}

\author{
Moses Karakouzian \\ Department of Civil and Environmental \\ Engineering and Construction, \\ University of Nevada Las Vegas, Las \\ Vegas, USA \\ mkar@unlv.nevada.edu
}

\begin{abstract}
Water resources are vital not only for human beings but essentially all ecosystems. Human health is at risk if clean drinking water becomes contaminated. Water is also essential for agriculture, manufacturing, energy production and other diverse uses. Therefore, a changing climate and its potential effects put more pressure on water resources. Climate change may cause increased water demand as a result of rising temperatures and evaporation while decreasing water availability. On the other hand, extreme events as a result of climate change can increase surface runoff and flooding, deteriorating water quality as well. One effect is water eutrophication, which occurs when high concentrations of nutrients, such as nitrogen and phosphorus, are present in the water. Nutrients come from different sources including agriculture, wastewater, stormwater, and fossil fuel combustion. Algal blooms can cause many problems, such as deoxygenation and water toxicity, ultimately disrupting normal ecosystem functioning. In this paper, we investigate the potential impacts of climatic factors affecting water eutrophication, how these factors are projected to change in the future, and what their projected potential impacts will be.
\end{abstract}

Keywords-climate change; water quality; eutrophication

\section{INTRODUCTION}

The planet is getting warmer as an impact of exponentially increasing anthropogenic greenhouse gas emissions, especially $\mathrm{CO}_{2}$. According to the fifth assessment report of the Intergovernmental Panel on Climate Change (IPCC), the global average surface temperature has undergone a warming of $0.85^{\circ} \mathrm{C}(0.65$ to 1.06$)$ from 1880 to 2012 , proving that global warming is occurring [1]. A warmer climate will affect the hydrological cycle and change atmospheric and meteorological properties such as precipitation patterns, atmospheric water vapor and evaporation [2-4], and consequently impact water quality by intensifying many forms of water pollution [5-7]. One form of water pollution is water eutrophication, which occurs when high concentrations of nutrients, such as nitrogen and phosphorus, are present in the water.

In recent years, specific concerns about the impacts of climate change on water eutrophication, which causes global environmental challenges regarding the management of water resources, have been raised [8-15]. The Fifth Global Environment Outlook (GEO-5) reports that more than $40 \%$ of water bodies all around the world suffer from different levels of eutrophication [16]. The reason for this phenomenon is an important issue of great concern is its potential consequences, threatening the reliable supply of drinking water [17-19]. The terminology and application of trophic development of freshwaters date back to the early twentieth century. The consequences of anthropogenic-induced eutrophication of freshwaters did not become evident until the 1940s and 1950s as public concern over the severity of surface water deterioration became evident and triggered expanding scientific interest. Scientists debated which nutrient is primarily responsible for limiting productivity in lakes and rivers, an issue known as limiting nutrient controversy, and they ultimately agreed that phosphorus $(\mathrm{P})$ is the key element in controlling eutrophication. [20]. Algal blooms in water bodies are a sign of eutrophication that indicates the presence of high concentrations of phosphorus and nitrogen. Algal blooms can form anoxic environments in the water and consequently deteriorate water quality $[10,15,21]$. Predictions indicate that with rising concentrations of atmospheric $\mathrm{CO}_{2}$, the occurrence of algae blooms will likely increase [22, 23]. Recent anthropogenic changes, such as urban, agricultural, and industrial development, have accelerated the progress of nutrient over-enrichment, leading to eutrophication in water bodies [24-26].

Undesirable symptoms of eutrophication primarily occur during the plant growing season (spring and summer), when low flow, high water residence times, sufficient light levels and high water temperature promote rapid algal growth. During the growing season, the eutrophication risk mainly originates from point discharges, a major source of high concentrations of dissolved, bioavailable phosphorus fractions. At times when diffuse agricultural runoff contributions are relatively low, phosphorus concentrations from point sources become even higher in the receiving water bodies, as a result of reduced effluent dilution [27]. The trophic state in flowing waters depends mainly on phosphorus and nitrogen levels. Hydraulic flushing of nutrients, light limitation, and water velocity are essential in controlling algal growth. This suggests that rivers or riverine lakes with short retention times ( $<3$ days) will show different effects compared to those with long retention times (>3 days) [28].

Climate change can, directly and indirectly, affect eutrophication, as a result of interactions between meteorological factors and nutrient availability [24, 29]. The 
existing literature shows that sensitive factors to climate change such as water temperature, precipitation, wind, and solar radiation can affect trophic conditions in water bodies. Therefore, to maintain water resources availability and safety, it is crucial to investigate the impacts of climate change on water quality in water resources. This paper briefly summarizes the potential impacts of climate change on the occurrence of eutrophication in water resources.

\section{Climate CHANGE EFFECTS}

\section{A. Temperature}

Regarding climate change, many factors are considered in order to predict how future global warming will occur. In this case, the amount of future greenhouse gas emissions is a key variable. Two different emissions scenarios, including RCP2.6 (low emissions scenario) and RCP8.5 (high emissions scenario), show that by the end of the 21 st century, the global surface temperature is expected to increase by $0.3^{\circ} \mathrm{C}-1.7^{\circ} \mathrm{C}$ and $2.6^{\circ} \mathrm{C}-4.8^{\circ} \mathrm{C}$ under RCP2.6, and RCP8.5, respectively [30]. Temperature is an important environmental factor that influences chemical and physical properties in water ecosystems such as $\mathrm{pH}$, salinity, solubility, and diffusion rates, and can consequently affect water eutrophication potential [31, 32]. Air temperature and temperature in water bodies are in close equilibrium. Hence one of the immediate reactions to climate change is expected to be alterations in river and lake water temperatures [22, 33-35]. When water temperature and nutrient concentrations increase, algae growth is stimulated, leading to water eutrophication and algal blooms. As concentrations of phosphorous and nitrogen increase in lakes, rivers and estuaries, cyanobacteria become increasingly dominant. Cyanobacteria are a group of bacteria that grow in any type of water (fresh, brackish, or marine) and use sunlight to create food and survive. Because of their color, they are commonly known as "blue-green algae". They grow quickly and bloom in warm, nutrient-rich environments. Water bodies experiencing frequent blooms of cyanobacteria show properties that can impact water quality as well as the health of the surrounding environment $[36,37]$. Once the water temperature rises above $25^{\circ} \mathrm{C}$, the growth of cyanobacteria accelerates [32, 38-40]. Similarly, warmer temperatures could also stimulate earlier and more extended periods of potential algal blooms, as the immediate direct effect of a warmer environment [31, 41, 42]. Moreover, warmer temperatures will affect nutrient loadings from soil and sediment, which can ultimately impact the trophic status of water [43].

As the inflow to a reservoir gets warmer as a result of higher temperature, the water column will stratify more intensely, decreasing nutrient availability in the surface water. In this case, cyanobacteria will obtain nutrients from deeper depths and accelerate nutrient release in water [44, 45]. Higher temperatures will accelerate microbial activity in sediments at the bottom of lakes and rivers. In this case, the release rate of internal phosphorus will increase, and will contribute to a significant portion of the total nutrient load in the water [46]. In addition, higher water temperatures will reduce the degradation coefficients of water and decrease its self-purification capacity [10]. Therefore, under climate change conditions, the release of nutrient loadings from internal sources could still make water eutrophic, even if external sources of nutrients, such as waste discharge and non-point pollution are restrained [47]. Moreover, when the surface water gets warmer, water viscosity will decrease, and as a result, nutrient diffusion will increase towards the surface. In this situation, larger phytoplankton (photosynthesizing microscopic biotic organisms that inhabit the upper sunlit layer of almost all oceans and bodies of fresh water on Earth) will sink, and cyanobacteria will become more abundant [38, 48, 49]. As a summary, increasing air temperature will increase water temperature and deteriorate water quality conditions by accelerating the eutrophication process in water bodies, which can cause environmental and health-related issues [23, 26, 46].

\section{B. Precipitation}

Besides the temperature effects, the change in hydrological regimes is also a consequence of climate change. As the temperature is predicted to rise, precipitation will not change uniformly [30]. Under the RCP2.6 and RCP8.5 scenarios, climate model mean projections for 2081-2100 compared to 1986-2005 indicate that annual mean precipitation will increase mostly around the equatorial Pacific and some high-latitude areas. However, projections show that mean precipitation is likely to decrease in certain mid-latitude and subtropical regions, although some increase in mean precipitation in many mid-latitude regions is also likely to occur under the same scenario. Therefore, in areas with projected higher precipitation, it is possible that intense extreme precipitation events will occur and cause more erosion and resuspension of sediments, ultimately resulting in higher concentrations of sediments and nutrients in receiving water bodies [24, 48]. Furthermore, these extreme events will increase contaminant discharge and affect non-point pollution by mobilizing them over land and increasing nutrient concentrations in receiving water bodies, consequently degrading water quality. [49, 5153]. Less precipitation can also increase the risk of eutrophication by lowering minimum flows. In this case, less water volume will be available for dilution of pollutants. As a result, increased concentration of contaminants can cause deoxygenation, by lowering dissolved oxygen concentration (DO) and increasing biochemical oxygen demand (BOD). Consequently, the risk of eutrophication, especially in water bodies with limited re-aeration capacity, will be increased [24, 54]. Therefore, under climate change conditions and due to the alteration of regional precipitation patterns, water bodies are exposed to greater nutrient loads, which can ultimately lead to water quality deterioration.

\section{Wind}

The wind will also be affected by climate change, and will have direct and indirect impacts on water resources [39]. Authors in [50] used general circulation models, under the A2 emission scenario, to predict the wind speed in different regions in 2050. Modeling results showed that across the boreal regions of the northern hemisphere, including Canada, tropical and subtropical regions, northern Europe, and Central and South America, stronger surface wind speeds will occur in 2050, while decreasing wind speeds were predicted for southern Europe, East and South Asia, and much of the west coast of South America. The direct effects of wind refer to 
blowing of algae from the water surface to the lakeshore or river banks and influencing these regions by forming algal blooms and changing environmental conditions. The indirect effect is the disturbance caused by the wind, which can circulate the water and mix different layers of the water column. This circulation enhances the mixture of nutrients and accelerates the release of nutrients from sediments [55]. Also, as the air temperature rises, wind mixes the warmer upper layers of water with the colder lower layers, which can speed up the volatilization, migration, and transformation of pollutants [9]. Authors in [56] used different sediment resuspension models to simulate nutrient distributions in the wind-dominated Salton Sea in the United States, which is highly eutrophic. They concluded that sediment resuspension, which induces both particulate and dissolved forms of nutrients, is the critical factor in nutrient cycling of the sea. Therefore, higher wind speeds will accelerate sediment resuspension, contaminant circulation, and finally exacerbate trophic conditions. Moreover, authors in [57] studied the Taihu Lake in China, which has experienced periods of severe eutrophication in the past. Model results, which coupled the biological processes and hydrodynamics in the lake, showed that temporal variations of eutrophication have high dependencies on meteorological forces. On the other hand, intense and high-speed winds can also restrain the formation of algal blooms by dissipating them and weakening their aggregation [58]. Therefore, the wind will have direct and indirect impacts on water trophic conditions, but it does not act as a single decisive operator, and mostly influences eutrophication along with other meteorological factors.

\section{Solar Radiation}

Global warming and solar radiation have mutual connections [59]. As an important source of energy, solar radiation plays a crucial role in photosynthesis in different ecosystems and is an essential factor for the growth of phytoplankton and other aquatic species. Therefore, the photosynthesis efficiency is dependent upon the temporal and spatial variations of solar radiation. Sufficient sunlight increases water temperature and the presence of nutrients altogether provide suitable conditions for the growth of algae and phytoplankton, finally resulting in water eutrophication [22]. Solar radiation affects a wide range of living organisms, by penetrating aquatic systems and acting as the energy source for plant photosynthesis. If plants do not receive sufficient amounts of sunlight, they take up oxygen from the water, and DO depletion will occur. Under anaerobic conditions, phosphorus release from sediments can cause water eutrophication [60,61]. Algae distribution is also dependent on the intensity of solar radiation received at different depths. However, increased sunlight will not necessarily cause more algae growth. There is a maximum growth rate for algae, in which beyond this threshold, the growth rate will decrease [62, 63]. Authors in [62] projected UV-B radiation at the Earth's surface from 1960 to 2100 . Although the global temperature is slated to rise until 2100, results of UV-B predictions showed that radiation change at different latitudes will alter differently. Projected UV-B radiation compared with 1980 levels, showed increasing trends at $60^{\prime \prime}$ to $90^{\prime \prime}$ southern latitude (more than $20 \%$ increase), and decreasing trends at $60 "$ to $90 "$ northern latitude (around 10\% decrease).

\section{E. Summary}

Besides the effects of temperature, precipitation, wind and solar radiation alteration, an increasing population, rapid urban development, and lack of land use planning continually contribute to the degradation of the environment and water resources. Figure 1 summarizes the impacts of climate change on water eutrophication.

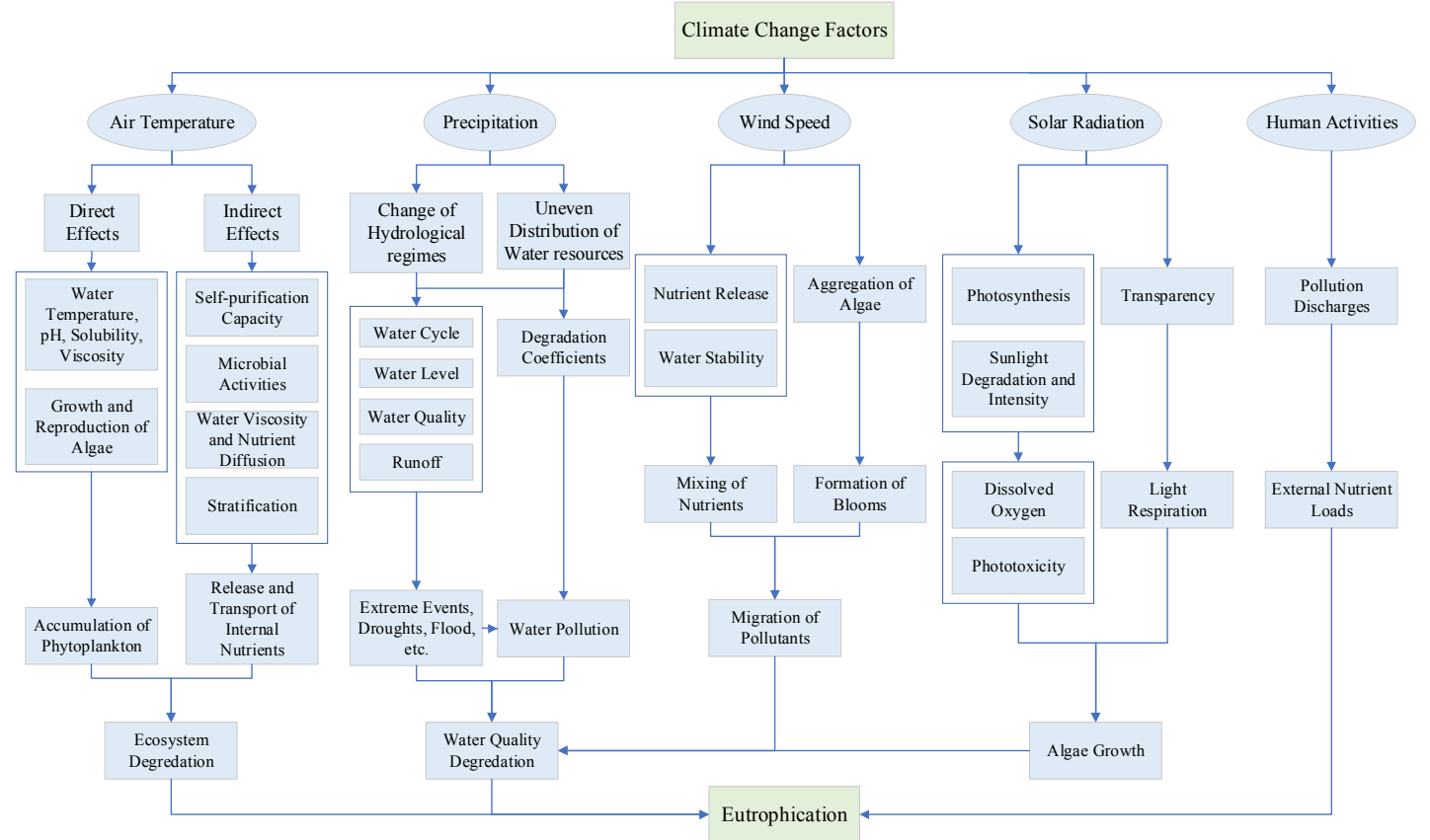

Fig. 1. The interaction among climate change factors and eutrophication. 


\section{CONCLUSION}

In this paper the effects of climate change on meteorological parameters such as temperature, precipitation, wind, and solar radiation were reviewed, and their potential impacts on water quality, especially eutrophication, were investigated. Based on the available literature and historical, scientific evidence, a changing climate will lead to degradation of water quality. The recent anthropogenic climate change will also amplify deterioration of trophic conditions in water resources, by changing the internal and external nutrient loadings, as an impact of global temperature rise, changing precipitation patterns, and altering wind speed and solar radiation intensity. Therefore, maintaining our invaluable water resources in a changing climate is a big and significant challenge for the policymakers today, and deserves considerable attention for the sake of future generations.

\section{REFERENCES}

[1] IPCC, IPCC Working Group I Contribution to the IPCC Fifth Assessment Report (AR5): The Physical Science Basis, IPCC, 2013

[2] IPCC, Climate Change 2007: The Physical Science Basis, Cambridge University Press, 2007

[3] IPCC, Managing the Risks of Extreme Events and Disasters to Advance Climate Change Adaptation, Cambridge University Press, 2012

[4] T. G. Huntington, "Evidence for intensification of the global water cycle: Review and synthesis", Journal of Hydrology, Vol. 319, No. 1-4, pp. 83-95, 2006

[5] R. Deus, D. Brito, M. Mateus, I. Kenov, A. Fornaro, R. Neves, C. Alves, "Impact evaluation of a pisciculture in the Tucuruí Reservoir (Para, Brazil) using a two-dimensional water quality model", Journal of Hydrology, Vol. 487, pp. 1-12, 2013

[6] S. Chung, J. Oh, "Calibration of CE-QUAL-W2 for a monomictic reservoir in a monsoon climate area", Water Science and Technology, Vol. 54, No. 11-12, pp. 29-37, 2006

[7] Y. Park, K. H. Cho, J. H. Kang, S. W. Lee, J. H. Kim, "Developing a flow control strategy to reduce nutrient load in a reclaimed multireservoir system using a 2D hydrodynamic and water quality model", Science of the Total Environment, Vol. 466-467, pp. 871-880, 2014

[8] J. Xia, S. Cheng, X. Hao, R. Xia, X. Liu, "Potential impacts and challenges of climate change on water quality and ecosystem: Case studies in representative rivers in China", Journal of Resources and Ecology, Vol. 1, No. 1, pp. 31-35, 2010

[9] R. Xia, Z. Chen, Y. Zhou, "Impact Assessment of Climate Change on Algal Blooms by a Parametric Modeling Study in Han River", Journal of Resources and Ecology, Vol. 3, No. 3, pp. 209-219, 2012

[10] B. Moss, D. McKee, D. Atkinson, S. E. Colliongs, W. J. Eaton, A. B. Gill, I. Harvey, K. Hatton, T. Heyes, D. Wilson, "How important is climate? Effects of warming, nutrient addition and fish on phytoplankton in shallow lake microcosms", Journal of Applied Ecology, Vol. 40, No. 5, pp. 782-792, 2003

[11] IPCC, Climate Change 1995, The Science of Climate Change Technical Report, Cambridge University Press, 1996

[12] K. Hiscock, A. Southward, I. Tittley, S. Hawkins, "Effects of changing temperature on benthic marine life in Britain and Ireland", Aquatic Conservation: Marine and Freshwater Ecosystems, Vol. 14, No. 4, pp. 327-331, 2004

[13] R. L. Wilby, P. G. Whitehead, A. J. Wade, D. Butterfield, R. J. Davis, G. Watts, "Integrated modelling of climate change impacts on water resources and quality in a lowland catchment: River Kennet, UK", Journal of Hydrology, Vol. 330, No. 1-2, pp. 204-220, 2006

[14] C. R. Fragoso Jr., D. M. L. Motta Marques, T. F. Ferreira, H. J. Janse, E. H. van Nes, "Potential effects of climate change and eutrophication on a large subtropical shallow lake", Environmental Modelling \& Software, Vol. 26, No. 11, pp. 1337-1348, 2011
[15] B. Moss, S. Kosten, M. Meerhoff, R. Battarbee, N. Mazzeo, K. Havens, G. Lacerot, Z. W. Liu, D. L. Meester, H. Paerl, M. Scheffer, "Allied attack: Climate change and eutrophication", Inland Waters, Vol. 1, No. 2, pp. 101-105, 2011

[16] United Nations Environment Programme, Global Environment Outlook Year Book: An Overview of Our Changing Environment, 2012

[17] G. M. Hallegraeff, "A review of harmful algal blooms and their apparent increase”, Phycologia, Vol. 32, No. 2, pp. 79-99, 1993

[18] I. Chorus, J. Bartram, Toxic Cyanobacteria in Water: A Guide to their Public Health Consequences, Monitoring and Management, World Health Organization, Geneva, 1999

[19] C. Le, Y. Zha, Y. Li, D. Sun, H. Lu, B. Yin, "Eutrophication of Lake Waters in China: Cost, Causes, and Control", Environmental Management, Vol. 45, No. 4, pp. 662-668, 2010

[20] G. E. Likens, Nutrients and Eutrophication: The Limiting Nutrient Controversy, American Society of Limnology and Oceanography, 1972

[21] C. Huang, X. Wang, H. Yang, Y. Li, Y. Wang, X. Chen, L. Xu, "Satellite data regarding the eutrophication response to human activities in the plateau lake Dianchi in China from 1974 to 2009", Science of the Total Environment, Vol. 1, No. 11, pp. 485-486, 2014

[22] S. Ihnken, A. Eggert, J. Beardall, "Exposure times in rapid light curves affect photosynthetic parameters in algae", Aquatic Botany, Vol. 93, No. 3, pp. $185-194,2010$

[23] H. W. Paerl, T. G. Otten, "Blooms Bite the Hand That Feeds Them", Science, Vol. 342, No. 6157, pp. 433-434, 2013

[24] P. G. Whitehead, R. L. Wilby, R. W. Battarbee, "A review of the potential impacts of climate change on surface water quality" Hydrological Sciences Journal, Vol. 54, No. 1, pp. 101-123, 2009

[25] B. M. Ulen, G. A. Weyhenmeyer, "Adapting regional eutrophication targets for surface waters-Influence of the EU Water Framework Directive, national policy and climate change", Environmental Science \& Policy, Vol. 10, No. 7-8, pp. 734-742, 2007

[26] H. W. Paerl, L. M. Valdes, A. R. Joyner, B. L. Peierls, M. F. Piehler, S. R. Riggs, R. R. Christian, L. A. Eby, L. B. Crowder, J. S. Ramus, E. J. Clesceri, C. P. Buzzelli, R. A. Luettich, "Ecological response to hurricane events in the Pamlico Sound System, NC and implications for assessment and management in a regime of increased frequency", Estuaries and Coasts, Vol. 29, No. 6, pp. 1033-1045, 2006

[27] H. P. Jarvie, C. Neal, P. J. A. Withers, "Sewage-effluent phosphorus: A greater risk to river eutrophication than agricultural phosphorus?", Science of the Total Environment, Vol. 360, No. 1-3, pp. 246-253, 2006

[28] J. Hilton, M. O'Hare, M. J. Bowes, J. I. Jones, "How green is my river? A new paradigm of eutrophication in rivers", Science of the Total Environment, Vol. 365, No. 1-3, pp. 66-83, 2006

[29] E. Jeppesen, M. Sondergaard, J. P. Jensen, K. Havens, O. Anneville, L. Carvalho, M. F. Coveney, R. Deneke, M. T. Dokulil, B. Foy, D. Gerdeaux, S. E. Hampton, S. Hilt, K. Kangur, J. Kohler, E. H. H. R. Lammens, T. L. Lauridsen, M. Manca, M. R. Miracle, B. Moss, P. Noges, G. Persson, G. Phillips, R. Portielje, S. Romo, C. L. Schelske, D. Straile, I. Tatrai, E. Willen, M. Winder, "Lake responses to reduced nutrient loading - An analysis of contemporary long-term data from 35 case studies", Freshwater Biology, Vol. 50, No. 10, pp. 1747-1771, 2005

[30] IPCC. Climate Change 2014: Synthesis Report. Contribution of Working Groups I, II and III to the Fifth Assessment Report of the Intergovernmental Panel on Climate Change, IPCC: Geneva, Switzerland, 2014

[31] W. M. Mooij, J. H. Janse, L. N. De Senerpont Domis, S. Hu lsmann, B. W. Ibelings, "Predicting the effect of climate change on temperate shallow lakes with the ecosystem model PCLake", Hydrobiologia, Vol. 584, No. 1, pp. 443-454, 2007

[32] J. Q. Su, H. Wang, Z. F. Yang, "Lake eutrophication modeling in considering climatic factors change: A review", Chinese Journal of Applied Ecology, Vol. 23, No. 11, pp. 3197-3206, 2012 (in Chinese)

[33] H. Hassan, T. Aramaki, K. Hanaki, T. Matsuo, R. L. Wilby, "Lake stratification and temperature profiles simulated using downscaled GCM output", Water Science \& Technology, Vol. 38, No. 11, pp. 217-226, 1998 
[34] D. Hammond, A. R. Pryce, Climate Change Impacts and Water Temperature, Environment Agency Science Report, 2007

[35] A. J. Liu, S. T. Y. Tong, J. A. Goodrich, "Land use as a mitigation strategy for the water-quality impacts of global warming: A scenario analysis on two watersheds in the Ohio River basin", Environmental Engineering and Policy, Vol. 2, No. 2, pp. 65-76, 2000

[36] H. K. Hudnell, Cyanobacterial Harmful Algal Blooms: State of the Science and Research Needs, Springer, 2008

[37] K. E. Havens, "Cyanobacteria blooms: effects on aquatic ecosystems", Advances in Experimental Medicine and Biology, Vol. 619, pp. 733747, 2008

[38] L. Peperzak, "Climate change and harmful algal blooms in the North Sea", Acta Oecologica, Vol. 24, No. 1, pp. 139-144, 2003

[39] C. S. Reynolds, Ecology of Phytoplankton (Ecology, Biodiversity and Conservation), Cambridge University Press, 2006

[40] K. D. Johnk, J. Huisman, J. Sharples, B. Sommeijer, P. M. Visser, J. M. Stroom, "Summer heatwaves promote blooms of harmful cyanobacteria”, Global Change Biology, Vol. 14, pp. 495-512, 2008

[41] D. Trolle, D. P. Hamilton, C. A. Pilditch, I. C. Duggan, E. Jeppesen, "Predicting the effects of climate change on trophic status of three morphologically varying lakes: Implications for lake restoration and management", Environmental Modelling \& Software, Vol. 26, No. 4, pp. 354-370, 2011

[42] R. P. Canale, A. H. Vogel, "Effects of temperature on phytoplankton growth", Journal of Environmental Engineering, Vol. 100, No. 1, pp. 229-241, 1974

[43] B. Dale, M. Edwards, P. C. Reid, "Climate change and harmful algal blooms", in: Ecology of Harmful Algae, Ecological Studies (Analysis and Synthesis), Vol. 189, pp. 367-378, Springer, Berlin, Heidelberg, 2006

[44] J. M. O'Neil, T. W. Davis, M. A. Burford, C. J. Gobler, "The rise of harmful cyanobacteria blooms: The potential roles of eutrophication and climate change", Harmful Algae, Vol. 14, pp. 313-334, 2012

[45] P. W. Boyd, S. C. Doney, "Modelling regional responses by marine pelagic ecosystems to global climate change", Geophysical Research Letters, Vol. 29, No. 16, pp. 51-53, 2002

[46] T. Valdemarsen, C. O. Quintana, M. R. Flindt, E. Kristensen, "Organic $\mathrm{N}$ and $\mathrm{P}$ in eutrophic fjord sediments - Rates of mineralization and consequences for internal nutrient loading”, Biogeosciences, Vol. 12, pp. 1765-1779, 2015

[47] M. A. Donald, M. P. Glibert, M. J. Burkholder, "Harmful algal blooms and eutrophication: Nutrient sources, composition, and consequences", Estuaries and Coasts, Vol. 25, No. 4b, pp. 704-726, 2002

[48] R. M. Vogel, I. Wilson, C. Daly, "Regional regression models of annual streamflow for the United States", Journal of Irrigation and Drainage Engineering, Vol. 125, No. 3, pp. 148-157, 1999

[49] E. G. Chung, F. A. Bombardelli, S. G. Schladow, "Modeling linkages between sediment resuspension and water quality in a shallow, eutrophic, wind-exposed lake", Ecological Modelling, Vol. 220, No. 910, pp. 1251-1265, 2009

[50] S. Eichelberger, J. Mccaa, B. Nijssen, A. Wood, Climate Change Effects on Wind Speed, North American Wind Power, Zackin Publications, 2011

[51] M. Edwards, A. J. Richardson, "Impact of climate change on marine pelagic phenology and trophic mismatch", Nature, Vol. 430, pp. 881884,2004

[52] L. E. Brown, D. M. Hannah, A. M. Milner, "Vulnerability of alpine stream biodiversity to shrinking glaciers and snowpacks", Global Change Biology, Vol. 13, No. 5, pp. 958-966, 2007

[53] K. W. King, J. C. Balogh, R. D. Harmel, "Nutrient flux in stormwater runoff and baseflow from managed turf', Environmental Pollution, Vol. 150, No. 3, pp. 321-328, 2007

[54] K. Kallio, S. Rekolainen, P. Ekholm, K. Granlund, Y. Laine, H. Johnsson, M. Hoffman, "Impacts of climate change on agricultural nutrient losses in Finland", Boreal Environment Research, Vol. 2, No. 1, pp. 33-52, 1997
[55] G. George, M. Hurley, D. Hewitt, "The impact of climate change on the physical characteristics of the larger lakes in the English Lake District", Freshwater Biology, Vol. 52, No. 9, pp. 1647-1666, 2007

[56] F. Wu, J. Y. Zhang, X. Z. Deng, Y. Z. Ling, "Influencing factors of Lake Eutrophication in China", Ecology and Environmental Sciences, Vol. 21, pp. 94-100, 2012

[57] J. Q. Mao, Q. Chen, Y. C. Chen, "Three-dimensional eutrophication model and application to Taihu Lake, China", Journal of Environmental Sciences, Vol. 20, No. 3, pp. 278-284, 2008

[58] S. Stanichny, Y. Ratner, M. Shokurov, R. Stanychina, D. Soloviev, V. Burdyugov, "Wind impact on the black sea ecosystem", EGU General Assembly, Vienna, Austria, May 2-7, 2010

[59] K. Frey, D. K. Perovich, B. Light, "The spatial distribution of solar radiation under a melting Arctic sea ice cover", Geophysical Research Letters, Vol. 38, No. 22, pp. 1-6, 2011

[60] B. Nesa, A. H. Baird, S. Harii, I. Yakovleva, M. Hidaka, "Algal symbionts increase DNA damage in coral planulae exposed to sunlight", Zoological Studies, Vol. 51, No. 1, pp. 12-17, 2012

[61] NEP, National "12th Five-Year Plan" for Environmental Protection; China Environmental Science Press: Beijing, China, 2012

[62] E. W. Craig, R. G. Zepp, R. M. Lucas, S. Madronich, T. A. Austin, C. L. Ballare, M. Norval, B. Sulzberger, A. F. Bais, R. L. McKenzie, S. A. Robinson, D. P. Hader, N. D. Paul, J. F. Bornman, "Solar ultraviolet radiation in a changing climate", Nature Climate Change, Vol. 4, pp. 434-441, 2014

[63] D. P. Hader, H. D. Kumar, R. C. Smith, R. C. Worrest, "Effects of solar $\mathrm{UV}$ radiation on aquatic ecosystems and interactions with climate change", Photochemical and Photobiological Sciences, Vol. 6, No. 3, pp. 267-285, 2007 